\title{
ISLAMISASI DAN PERKEMBANGAN KERAJAAN HOAMOAL DI SERAM BAGIAN BARAT
}

\section{The Islamization and The Development of Hoamoal Kingdom of Western Seram}

\author{
Wuri Handoko \\ Balai Arkeologi Ambon \\ J1. Namalatu-Latuhalat 97118 \\ wuri_balarambon@yahoo.com
}

Naskah diterima : 06-02-2014 ; direvisi : 05-08-2014 ; disetujui : 05-09-2014

\begin{abstract}
Hoamoal kingdom is one of the Islamic empire in the Moluccas Islands, precisely in Ceram which has an important role in the movement of Islamization in Central Moluccas region. This study with emphasis on archaeological survey method to collect physical data or artefaktual, then do the processing and analys is of data to explain the influence of Islam in the region. This study aims to look at developments in the history of the Kingdom Hoamoal Islam and trade in the region of Central Moluccas, and saw its role in supporting the Islamization movement in the region. The result showed that the growth of the Kingdom Hoamoal explanation can not be separated from the influence of Ternate in the form of Islamization and trade networks.
\end{abstract}

Keywords: Kingdom, Hoamoal, Islamization, Trade

\begin{abstract}
Abstrak
Kerajaan Hoamoal adalah salah satu kerajaan Islam di wilayah Kepulauan Maluku, tepatnya di Pulau Seram yang memiliki peran penting dalam gerak Islamisasi di wilayah Maluku Tengah. Penelitian ini dengan menekankan pada metode survei arkeologi untuk mengumpulkan data fisik atau artefaktual, kemudian melakukan pengolahan dan analisis data untuk menjelaskan pengaruh Islam di wilayah tersebut. Penelitian ini bertujuan untuk melihat perkembangan Kerajaan Hoamoal dalam sejarah perkembangan Islam dan perdagangan di wilayah Maluku Tengah, serta melihat perannya dalam menunjang gerak Islamisasi di wilayah tersebut. Dari hasil penelitian diperoleh penjelasan bahwa berkembangnya Kerajaan Hoamoal tidak terlepas dari pengaruh Ternate dalam membentuk jaringan Islamisasi dan perdagangan.
\end{abstract}

Kata Kunci : Kerajaan, Hoamoal, Islamisasi, Perdagangan

\section{PENDAHULUAN}

Gerak Is lamisasi dan perkembangannya, merupakan salah satu entitas penting perkembangan sejarah dan peradabaan masyarakat di wilayah Kepulauan Maluku. Dalam historiografi Islam di wilayah Kepulauan Maluku, eksistensi Islam yang paling kuat dianggap berpusat di wilayahwilayah empat kerajaan besar di wilayah Maluku Utara itu. Di daerah lainnya di bagian selatan Kepulauan Maluku atau yang saat ini termasuk dalam wilayah administratif
Propinsi Maluku, penting untuk ditelusuri kembali bagaimana proses penyebaran dan pengaruh kekusaan Islam berlangsung, mengingat daerah ini dianggap sebagai daerah perluasan kekuasaan dan penyebaran Islam. Kerajaan-kerajaan Islam di wilayah Maluku bagian selatan, budaya masyarakat dengan corak Islam cukup berkembang, namun perkembangannya menjadi daerah Kesultanan seperti halnya di wilayah Maluku Utara tidak terwujud dan ketika pada masa hegemoni kolonial kerajaan-kerajaan ini mengalami 
kemunduran dan kalah dalam peperangan dan politik (Putuhena, 2001-58). Oleh karena itu penelitian arkeologi penting dilakukan untuk melihat sejauh mana perkembangan Islam berlangsung assosiasinya dengan pengaruh kekuasaan sekaligus perluasan jaringan perdagangan.

Perkembangan kemudian, Ternate dan Tidore bersaing memperoleh legitimasi politik sebagai wilayah pusat kekuasaan Islam, sehingga masing-masing kerajaan tersebu bersaing untuk memperluas kekuasaannya. Ternate berekspansi ke wilayah Seram Bara yakni Jazirah Hoamoal tempat berdirinya Kerajaan Hoamoal dan ke wilayah Pulau Ambon, sementara Tidore berekspansi ke wilayah pesisir utara Pulau Seram, Pulau Gorom dan Seram Laut di bagian timu Pulau Seram, bahkan mencapai Raja Empat, Irian. Peranan Ternate dan Tidore sebaga bandar jalur sutera dengan sendirinya terkait dengan ekspansi itu (Leirizza, 2001: 7-8). Seiring dengan itu, perluasan agama Islam dari kedua kerajaan tersebut juga menyebar. Sejarah mencatat, Ternate dan Tidore adalah dua kerajaan di wilayah Maluku Utara yang dapat dipresentasikan sebagai wilayah pusa kekuasaan Islam di wilayah Maluku Utara. kekuasaan ke wilayah selatan Maluku, meliputi Pulau Ambon, Haruku, Saparua, Buru, Seram Bagian Bara dan Tengah. Sementara itu Tidore melebarkan sayap kekuasaannya ke wilayah pesisir utara Pulau Seram dan wilayah kepulauan di sis paling timur Pulau Seram, yakni Gorom dan Seram Laut hingga ke wilayah Kepulauan Raja Ampat Irian Jaya (Leirissa, 2001:8) Kedua wilayah kesultanan itu dianggap saling bersaing dalam memperluas kekuasaannya hingga keluar wilayah geografisnya ke wilayah pulau-pulau di seberang lautan.

Sejauh ini dokumen sejarah dan tradisi tutur banyak mengungkapkan gera Islamisasi di hampir seluruh wilayah Kepulauan Maluku. Dokumen sejarah juga banyak menuliskan bagaimana kiprah Islam dalam menguasai jaringan perdagangan dan ekonomi, bahkan dalam struktur politik, dengan munculnya kerajaan-kerajaan Islam. Diantara kerajaan-kerajaan ini terdapa pusat-pusat peradaban Islam yang meluaskan kekuasaan ke wilayah-wilayah lainnya. Dalam catatan sejarah, sangat minim atau terbatas sekali informasi tentang wilayah-wilayah penyebaran Islam. Dalam aspek Islamisasi, kita sulit menemukan informasi atau petunjuk bagaimana masyarakat mengkonversi dan mengadopsi Islam, serta bagaimana proses Islamisasi berlangsung, dalam korelasinya dengan kekuasaan dan politik, serta bagaiman gerak niaga wilayah-wilayah pengaruh Islam dalam mempertahankan eksisitensinya.

$$
\text { Untuk melihat bagaimana pengaruh }
$$

Islam di wilayah penyebaran Islam dar pusat kekuasaan Islam, penelitian ini dengan lokus di wilayah Luhu, yakni wilayah pusat Kerajaan Hoamoal di Seram Bagian Barat, yang disebut dalam sejarah dan tradisi lisan sebagai wilayah kekuasaan Islam Ternate. Berdasarkan hal itu, permasalahan penelitian ini dirumuskan sebagai berikut:

1. Sejak kapan Islamisasi berlangsung di wilayah tersebut dan siapa pihak penyebar Islam di wilayah tersebut ?

2. Bagaimana gerak dan jaringan niaga berlangsung dalam mempertahankan eksistensinya sebagai kerajaan Islam?

Kerajaan Ternate, Tidore, Jailolo, dan Bacan di Maluku Utara, dianggap sebaga pusat kekuasaan Islam, karena di wilayah inilah Islam pertama kali berkembang. D wilayah Pulau Ambon, Kerajaan Hitu juga dianggap sebagai pusat peradaban dan kekuasaan Islam yang sezaman dengan Ternate. Jika kehadiran Islam dianggap sebagai kekuatan transformatif, telah memberdayakan masyarakat untuk keluar dari paham-paham primitif, serta dianggap mampu memberikan andil terhadap perubahan penting di bidang sosial dan struktur politik (Mahmud, 2001:73), maka di wilayah Maluku, wilayah-wilayah pusat kekuasaan Islam seperti yang disebutkan diawal, dapa dikatakan mewakili anggapan itu. Pusat-pusa kekuasaan Islam Maluku telah berkembang menjadi daerah kesultanan yang melebarkan wilayah seberang' Selain pelebaran sayap kekuasaan yang bersifat politis, kerajaankerajaan besar tersebut juga menyebarkan dan mengembangkan paham-paham bersifat kultural, yakni penyebaran dan pengembangan agama Islam di wilayah-wilayah pelebaran kekuasaan tersebut. Pengislaman 'wilayah seberang' kesultanan Ternate, tidak lepas dari peranan pusat kekuasaaan Islam. (Putuhena, 2001: 60)

Proses pengislaman wilayah-wilayah seberang di wilayah Kepulauan Maluku dan Maluku Utara, biasanya selain karena ekspansi politik, juga dibarengi dengan perluasan perdagangan akibat persaingan kerajaan untuk menguasasi jaringan ekonomi. Eksistensi kekuasaan Islam terutama di wilayah Maluku, tak bisa dilepaskan dari kegiatan perdagangan, hal ini mengingat penyebaran pengaruh Islam salah satunya dimulai melalui aktivitas niaga oleh para pedagang muslim, meskipun sebagian ahli berpendapat, perdagangan tak berkaitan langsung dengan Islamisasi (Ricklefs 2008: 36). Ia juga menuliskan bahwa antara Islam dan perdagangan tampaknya ada semacam kaitan, meskipun banyak pertanyaanpertanyaan yang belum terjawab, mengingat perdagangan oleh orang-orang muslim telah ada beberapa abad sebelum masa pengislaman Nusantara yang baru terjadi pada abad ke- 13 dan terutama abad ke 14 dan $15 \mathrm{M}$ (Rickle tersebut memberikan gambaran bahwa proses perdagangan di wilayah Nusantara berlangsung jauh sebelum Islam berkembang, sehingga jika Islamisasi berlangung sejak dimulainya era perdagangan oleh bangsabangsa penyebar Islam, semestinya Islam tumbuh dan berkembang sejak masa itu. Namun, satu hal yang tak dapat dipungkiri bahwa proses perdagangan yang berlangsung telah memperkuat eksistensi Islam di Nusantara. Tjandrasamita memperkuat dengan penjelasan bahwa munculnya jalur perdagangan sejak masa awal telah memicu terjalinnya jaringan perdagangan dan pertumbuhan serta perkembangan kota-kota pusat kesultanan, dengan kota-kota bandarnya sejak abad ke 13-18 M (Tjandrasamitha, 2009:39).

Berdasarkan landasan teoritis in maka, penelitian ini dilakukan dalam rangk menelusuri kembali jejak pengaruh Islam di wilayah yang dianggap sebagai wilayah kekuasaan dari pusat kekuasaan Islam. Penelitian ini juga berupaya mengidentifikasi bagaimana Islam berlangsung dalam korelasinya dengan gerak dan jaringan niaga di wilayah kepulauan Maluku.

\section{METODE}

Dalam Penelitian ini, lokus penelitian diarahkan di wilayah jazirah Hoamoal, pesisi Seram Bagian Barat, yang berpusat di Desa Luhu. Desa Luhu, secara administrative termasuk dalam wilayah Kecamatan Hoamoal, Kabupaten Seram Bagian Barat.

Lokasi penelitian ini dipilih mengingat berdasarkan teks sejarah merupakan wilayah penyebaran kekuasaan Islam Ternate. Selain itu, sejarah lisan daerah disebutkan sebagai salah satu bekas wilayah kerajaan Islam, taklukan dari Kerajaan Ternate, namun penelitian lebih lanjut untuk hal itu belum dilakukan. Selain itu secara arkeologis belum ditemukan bukti-bukti peninggalan kerajaan Islam dimaksud serta belum diperoleh penjelasan perkembangan budaya masyarakatnya, terutama perkembangan budaya Islam awal. Survei juga dia rahkan ke wilayah pulau-pulau kecil di sekitar jazirah Hoamoal, yang diperkirakan sebagai wilayah penyebaran Islam dari wilayah Hoamoal.

Pengumpulan data dilakukan melalu survei lapangan yang merupakan kegiatan pengamatan secara langsung di kawasan situs yang bertujuan mencari dan menemukan data-data di permukaan tanah. kegiatan survei terutama diarahkan pada daerahdaerah yang di dudga sebagai wilayah bekas permukiman komunitas melayu. Selain itu juga penting melakukan pendeskripsian bangunan monumental yang dijumpai, 
dilakukan serinci mungkin menyangkut deskripsi metrik, desain arsitektur, tipologi bangunan dan atribut kuat lainnya seper hiasan dan sebagainya. Diharapkan hasi pendeskripsian ini dapat memberi gambaran tentang pengaruh teknologi dan aspek sosia budaya.

Studi Pustaka, dalam tahap ini, dilakukan penggalian informasi dengan mengumpulkan dan mempelajari sumbersumber tertulis (literatur) tentang sejara dan budaya masyarakat di wilayah Hoamoal, khususnya di Desa Luhu. Mempelajari teks sejarah yang budaya dan perkembangan Islan di wilayah Ternate, yang dioanggap sebagai wilayah berpengaruh terhadap perkembangan Islam di Hoamoal. Teks-teks sejarah terutam menyangkut proses Islamisasi dan aktifita perdagangan. Data kepustakaan yang perlu dipelajari dan dikaji juga menyangku catatan-catatan etnografis tentang budaya lokal masyarakat setempat.

Wawancara adalah kegiatan menggali informasi dari masyarakat. Hal ini penting untuk memperoleh informasi dari masyarakat, terutama mencari target sasaran masyarakat melayu, maupun tokoh masyarakat ternate yang mengetahui keberadaan perkampungan melayu. Metode wawancara dilakukan dengan cara wawancara terbuka, sehingga memungkinkan memperoleh informasi yang lebih luas dari informan

\section{HASIL DAN PEMBAHASAN}

Hasil penelitian menunjukkan bahwa terdapat dua hal penting dalam Islamisasi dan perkembangan Kerajaan Hoamoal, yaitu: (1) Data sejarah berkaitan dengan perkembangan Kerajaan Hoamoal, (2) Data Arkeologi jejak Islamisasi di wilayah Kerajaan Hoamoal.

\section{Data Sejarah Berkaitan dengan} Perkembangan Kerajaan Hoamoal

Desa Luhu yang sekarang, pada masa lampau adalah Ibukota sekaligus juga pusat pemerintahan dari Kerajaan Luhu atau juga sering disebut Kerajan Hoamual. Sejak kapan Kerajaan Hoamoal didirikan, kini masih dalam penelitian, namun sejarah tutur menyebut bahwa pemerintahan pertama sudah berlangsung sejak awal abad ke 17 (1600an M) yakni ketika utusan Ternate Gimelah Ruhobongi dan dilanjutkan oleh Gimelaha Bassi memerintah di Hoamoal. Selain itu Kerajaan Hoamoal kemungkinan sudah ada sebelum bangsa-bangsa Asing seperti Cina, India, Persia, Arab, Spanyol, Potugis, Ingris dan Belanda datang ke Indonesia termasuk Maluku untuk berdagang dan menyiarkan agama.

Di Maluku sudah terdapat banyak kerajaan kecil, salah satu diantara kerajaankerajaan kecil adalah Kerajaan Hoamul. . meliputi seluruh Jasirah Hoamual dan sampai ke pulau-pulau yang berhadapan dengan tanah genting. Kotania, yaitu Pulau Manipa, Pulau Kelang, Pulau Buano serta pulau-pulau kecil disekitarnya. Kejayan Kerajan Hoamual mengalami keruntuhan akibat kekerasan Bangsa Belanda yang ingin memonopol hasil cengkeh di Kerajaan Homoal selama kurang lebih 31 tahun, yang juga dibarengi dengan penebangan cengkeh (Ekstirpasi) oleh pasukan Hongitochtennya, yakni menebang atau menebas seluruh kebun cengkeh di wilayah Kerajaan Hoamoal. Hal ini berkaitan dengan keberhasilan Gubernur de Vlaming pada Januari 1652, untuk mendesak Sultan Ternate Mandar Syah menandatangan perjanjian tentang pelarangan penanaman pohon cengkeh di wilayah Maluku (dan (a) kecuali di Pulau Ambon dan pulau-pulau kecil di sekitarnya. Perang yang berlangsung dari tahun 1625-1656 itu dikenal dengan nama Perang Hoamual. Perang tersebut berhasil meluluh lantakan sendisendi kehidupan Kerajaan Hoamoal. Paska Perang Hoamual tepatnya mulai tanggal 6 Maret 1656 Belanda melakukan deportas (pemindahan Penduduk secara paksa) sebagai bagian dari politik pecah belah (Devide et Impera). Akhirnya, kekuasaan Kerajaan Hoamual yang dulu konon meliputi 99 desa dusun, kini hanya tinggal sebuah desa yaitu Desa Luhu dengan 16 dusun bawahannya.
Dalam berbagai sumber sejarah disebutkan bahwa Kerajaan Hoamoal adalah wilayah ekspansi dari kekuasaan Islam Ternate. Wilayah-wilayah persebaran dari kekuasaan Ternate di wilayah Maluku bagian selatan, termasuk dalam hal ini adalah Kerajaan Hoamoal merupakan dampak dari persaingan antara dua kerajaan pusat kekuasan Islam di Maluku Utara, yakni Ternate dan Tidore. Perkembangan lanjut, Ternate dan Tidore. Perkembangan lanjut,
Ternate dan Tidore bersaing memperoleh legitimasi politik sebagai wilayah pusat kekuasaan Islam, sehingga masing-masing kerajaan tersebut bersaing untuk melebarkan sayap kekuasaannya. Ternate berekspansi ke wilayah Seram Barat yakni Jazirah Hoamoal, ke wilayah Pulau Ambon, sementara Tidore berkespansi ke wilayah pesisir utara Pulau Seram, Kepulauam Gorom dan Seram Laut di bagian timur Pulau Seram, bahkan mencapai Kepulauan Raja Empat, Irian. Peranan Ternate dan Tidore sebagai bandar jalur sutera dengan sendirinya terkait dengan ekspansi itu (Leirizza, $2001: 7$ ).

Seiring dengan itu, berlangsung pula secara serentak proses perluasan agama Islam dari kedua kerajaan tersebut. Sejarah mencatat, Ternate dan Tidore adalah dua kerajaan di wilayah Maluku Utara yang dapat dipresentasikan sebagai wilayah pusat kekuasaan Islam di wilayah Maluku Utara. Ternate, melakukan perluasan kekuasaan ke wilayah selatan Maluku, meliputi Pulau Ambon, Haruku, Saparua, Buru, Seram bagian barat dan tengah. Sementara itu Tidore ke wilayah pesisir utara Pulau Seram dan wilayah kepulauan di sisi paling timur Pulau Seram, yakni Gorom dan Seram Laut hingga ke wilayah Kepulauan Raja Ampat Irian Jaya (Leirissa, 2001:8). Dapat dianggap kedua wilayah kesultanan itu saling bersaing dalam hal hegemoni kekuasaan hingga keluar wilayah geografisnya ke wilayah pulau-pulau diseberang lautan.

Catatan lain yang mendukung bahwa wilayah Kerajaan Hoamoal merupaka bagian dari kekuasaan Ternate, yakni ketika Ternate menempatkan wakilnya, Gimelaha yang memerintah di wilayah-wilayah yang dikuasai Ternate di Maluku Tengah. Gimelah Bassi sebagai wakil Ternate, berkedudukan di wilayah yang disebut Gamsugi, di pantai timu Jasirah Hoamoal, yakni kota Pelabuhan Luhu, sebagai Gimelaha kedua yang memerinta hingga tahun 1612 (Leirizza, 1973: 48).

Dalam catatan sejarah dan sumbe

lisan, kekuasaan Gimelaha berawal dar tahun 1600-1656, yakni masa kemenangan VOC atas Portugis dimana saat itu Ternate bermitra dengan VOC, hingga masa jatuhny Kerajaan Hoamoal akibat politik VOC atas persetujuan Ternate dalam operasi Hongitochten Kebijakan ini diikuti pula dengan pemusatan penanaman pohon pala $\mathrm{di}$ Kepulauan Banda (Ricklefs. M.C. 2008 :102).

Untuk menjamin pelaksanaan perjanjian ini, Belanda menerapkan kebijakan pelayaran hongi atau ekspedis hongitochten. Pelayaran hongi atau armada hongi adalah pengerahan armada kapal yang dipersenjatai untuk melakukan pengawasan terhadap daerah-daerah penghasil cengkeh. Pelayaran hongi telah berlangsung sejak masa pendudukan Portugis dan sistem in dilanjutkan oleh Belanda setelah berhasi merebut penguasaan atas wilayah ini. Sejak pemerintahan Portugis, telah berlangsung hubungan antara penduduk Leitimor (bagian timur Pulau Ambon) untuk menyediakan perahu pengangkut yang disebut dengan korakora (perahu tradisional Maluku). Armada inilah yang kemudian digunakan untuk melaksanakan pelayaran hongi atau pada masa Belanda disebut ekspedisi hongitochten (Patikayhatu, dkk., 2009: 26). Dalam upaya menguasai perdagangan cengkeh, bangsa Eropa melakukan pembatasan penanaman pohon agar pasokan cengkeh dapat dijaga dan harga dapat dipertahankan. Kejayan Kerajan Hoamual mengalami keruntuhan akibat kekerasan Bangsa Belanda yang ingin memonopoli hasil cengkeh di kerajaan Hoamual selama kurang lebih 31 tahun, yang juga dibarengi dengan penebangan cengkeh (Ekstirpasi) oleh pasukan Hongitochtennya. Perang yang berlangsung dari tahun 1625 - 
1656 itu dikenal dengan nama Perang Hoamual. Perang tersebut berhasil meluluh lantakan sendi-sendi kehidupan Kerajaan Hoamual. Paska Perang Hoamual tepatnya mulai Tanggal 6 Maret 1656 kekuasaan Kerajaan Hoamual runtuh, dan banyak penduduk yang direlokasi secara paksa.

Data Arkeologi Jejak Islam di Wilayah Kerajaan Hoamoal

Pertama, di Desa Luhu Situs Desa Luhu terdapat situs Batu Kapal, Masjid Jam Luhu dan Data artefaktual Koleksi Penduduk. Di areal Situs Batu Kapal, ditemukan sebuah makam kuno berorientasi utara selatan, yang menandakan makam Islam. Makam in tampaknya merupakan sebuah makam kuno yang memiliki nisan berupa nisan menhir. Situs batu kapal ini, terdiri dari situs terbuka (open site), merupakan lahan datar yang kemungkinan sebagai situs hunian, sekaligus sebagai pertahanan, mengingat ditemukannya struktur batu yang mengelilingi areal datar. Di areal ini ditemukan sebaran keramik Dian gerabah yang cukup padat. Situs in berjarak sekitar $2 \mathrm{~km}$ dailokas negeri Luhu sekarang. Dalam sumber tutur diperoleh informasi bahwa Situs Batu Kapal, adalah lokasi pertahanan terakhir, sebelum Luhu dibumihanguskan oleh VOC dalam periode perang Hongi. Sebaran keramik yang padat, didominasi oleh keramik China periode Dinasti Ming (16-17) dan Dinasti Qing (17 19) (Tim Penelitian, 2012: 31)

Sementara itu gerabah dalam jumlah yang lebih sedikit juga ditemukan di areal tersebut. Hasil analisis morfologi fragmen gerabah yang ditemukan, menunjukkan temuan didominasi oleh gerabah sebagai peralatan sehari-hari. in selain sebagai situs benteng pertahanan, juga dimanfaatkan sebagai hunian, mungkin oleh para tentara atau prajurit kerajaan pada masa perang melawan VOC. Tampaknya hunian, hanya berlangsung pada masa perang mempertahankan Luhu dari serangan VOC pada masa abad ke 17 M. (Tim Penelitian, 2012: 36).

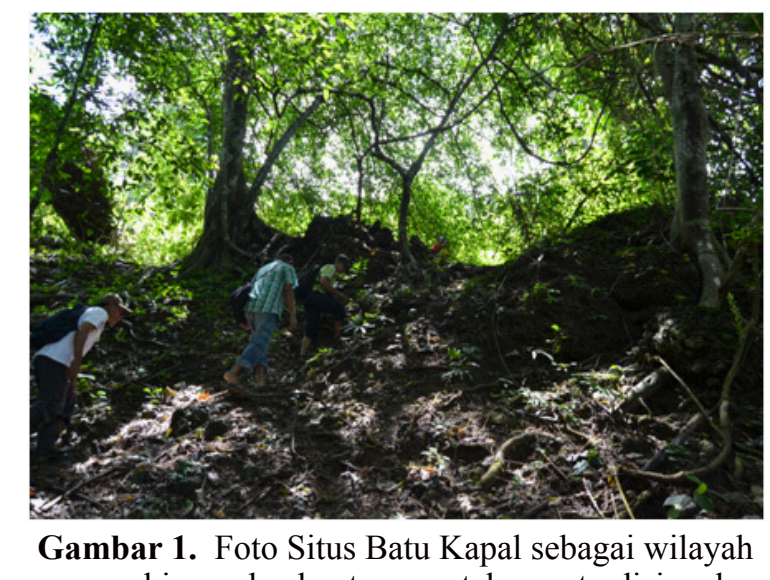

Gambar 1. Foto Situs Batu Kapal sebagai wilayah pemukiman dan benteng pertahanan tradisis
Kerajaan Hoamoal pada abad ke $17 \mathrm{M}$.

(Sumber : Dokumen Balai Arkeologi Ambon, 2012)

Masjid Luhu, merupakan Masjid Jami Negeri Luhu yang sudah mengalam perombakan, sehingga nyaris tidak ada tanda-tanda kekunoannya. Ciri kunonya diperlihatkan dari empat tiang di tengah ruangan serta bedug masjid yang diletakkan di serambi masjid. Sementara itu, bagian tangga masjid, yang sudah diperbaharui, menurut sumber tutur disebutkan bahwa jumlah 12 anak tangga menyimbolkan 12 marga yang ada di Negeri Luhu. Berdasarkan keterangan masyarakat, masjid pertama kalinya dibangun pada pertengahan abad ke $17 \mathrm{M}$, setelah utusan Ternate secara resmi memerintah Hoamoal.

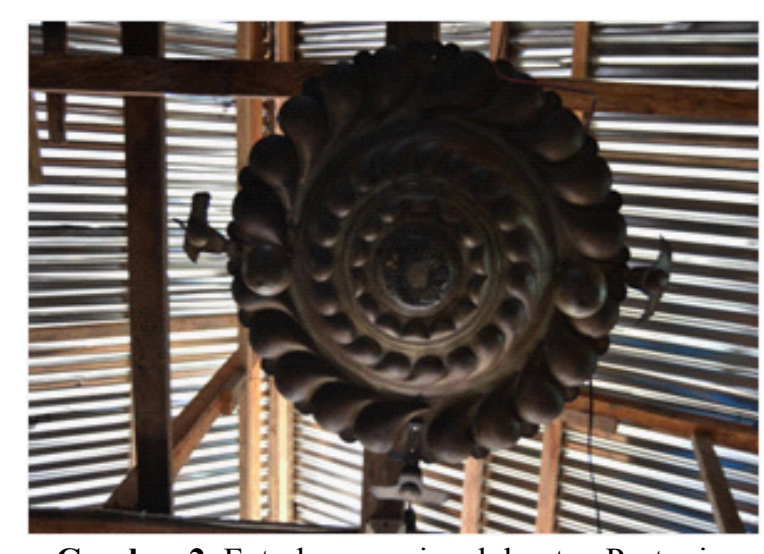

mbar 2. Foto lampu minyak buatan Portugis, berbahan kuningan, sebagai salah satu al kelengkapan masjid.

Kologi Ambon, 2012)

Data artefaktual Koleksi Penduduk, meliputi tombak, lampu minyak kelapa, koleksi keramik asing dan gerabah. Tombak terbuat dari logam besi pada mata tombaknya, dengan bentuk runcing pipih. Tombak berbentuk seperti ini, tampak sebagai pusaka atau alat perang yang kemungkinan berasal dari Jawa. Lampu minyak kelapa di desa Luhu, terbuat dari bahan kuningan. Lampu minyak ini biasanya sebagai salah satu alat kelengkapan masjid kuno. Di Luhu, lampu minyak menjadi koleksi atau benda pusaka dari salah satu keluarga atau mata rumah di Desa Luhu. Sementara itu Pedang ang menjadi koleksi penduduk, menunjukkan pedang yang diproduksi dari Eropa.

Temuan keramik, beberapa diantaranya menjadi koleksi penduduk, selain temuan dalam bentuk pecahan yang ditemukan di permukaan tanah pada situs-situs yang di survey. Temuan keramik, koleksi penduduk merupakan wadah yang dipergunakan seharihari antara lain jenis mangkuk besar, mangkuk kecil dan piring serta cawan. Warna glasir pada umumnya putih kebiru-biruan. Warna bahan putih keabu-abuan, dengan motif hias flora berwarna biru. Jenis keramik ini berasal dari China, kemungkinan dari masa Dinasti Ming (Abad 16-17) dan Qing (17-19 M).
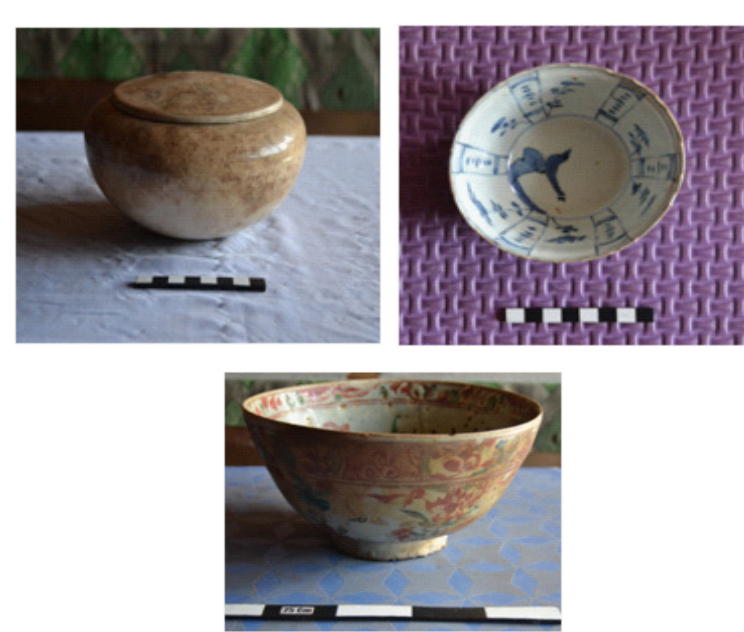

Gambar 3, 4, dan 5. Foto berbagai bentuk keramik asing yang menjadi koleksi penduduk di Neger
Luhu, wilayah bekas pusat Kerajaan Hoamoal

(Sumber: Dokumen Balai Arkeologi Ambon, 2012)

Kedua, di Desa Wayasell, terdapat situs Kota Mulu'. Di areal situs tersebut ditemukan batu meja dan makam kuno
Islam. Data arkeologi yang penting dari situs Wayasell adalah situs negeri lama yang disebut sebagai Kota Mulu. Dalam tradisi tutur masyarakat Luhu, Kota Mulu, sesungguhnya menunjuk pada toponim pusa kota awal Kerajaan Hoamoal. Kota Mulu pengertianya adalah Kota Raja, disinilah wal mula pusat Kerajaan Hoamoal, sebelum kemudian pindah di Negeri Luhu (Abdu Wahab Sunet, pers.com, 2012). Kampung kuno atau negeri lama Wayasel, terletak di perbukitan dengan ketinggian $250 \mathrm{M}$ dpl. Tempat ini berjarak $2 \mathrm{~km}$ dari dusun Air papaya atau mendekati perbatasan Desa Air papaya dengan Desa Wayasell. Secara administratif situs ini masuk dalam wilayah Dusun Wayasel. Masyarakat menyebutnya sebagai Kota Mulu'. Daerah ini merupaka padang datar dengan luas mencapai $200 \mathrm{M}^{2}$ Pada areal seluas 100 × $50 \mathrm{M}$, ditemukan sebaran keramik dan gerabah. Di duga area nilah adalah pusat kampung negeri lama Wayasel (Tim Penelitian, 2007: 12).

Berdasarkan identifikasi bentuknya, gerabah yang ditemukan di situs ini pada umumnya merupakan wadah, diantaranya tempayan, mangkuk dan piring. Bentuk wadah ini umumnya dipergunakan sebagai alat sehari-hari Ditemukan pula beberapa sampel gerabah hias. Yang menarik salah satunya berupa mangkuk berkaki yang memperlihatkan bentuk semacam pedupaan. Diduga kuat temuan ini khusus digunakan sebagai alat upacara keagaamaan oleh masyarakat. Mangkuk ini merupakan wadah dengan pola hias yang menunjukkan motif hias asli Maluku. Pola hias menunjukkan corak asli Maluku berupa motif geometris, garis-garis dan garis lengkung setengan lingkaran dengan panel-panel lingkaran dan motif hias bintik-bintik. Teknik hias menggunakan teknik gores dan cukil. Pada umumnya gerabah yang ditemukan berbahan tipis dengan bahan pembuatan yang lebih halus. Ciri ini menunjukkan perkembangan teknologi pembuatan gerabah yang lebih maju. 
Di areal ini juga ditemukan batu meja terletak sekitar 160 meter dari negeri lama Wayasel (Kota Mulu'). Melihat posisinya, masih terletak di areal kampung lama, mengingat jarak yang relatif dekat, dengan intensitas temuan gerabah yang masih dijumpai di titik-titik jalur menuju lokas batu meja dari kampung lama. Disekeliling batu, disusun batu gamping yang menjadikan semacam pembatas yang berjarak hanya sekitar $50 \mathrm{~cm}$ dari posisi batu meja. D sekitar batu meja juga tampak pagar batu atau benteng berupa gundukan tanah yang telah ditumbuhi semak belukar. Benteng/pagar batu yang masih tampak berada di sebelah utara dan timur batu meja dengan jarak sekitar 15 meter. Di sekitar batu meja merupakan areal semak belukar dan pohon-pohon besar (Tim Penelitian, 2007:13)

Di sebelah berat batu meja dengan jarak sekitar $50 \mathrm{~m}$ terdapat sebuah makam kuno. Makam kuno tersebut berupa gundukan tanah dikelilingi susunan batu yang tidak menutup keseluruhan pemukaan makam. Susunan batu nampaknya digunakan sebaga jirat dengan menggunakan satu nisan. Nisan kubur berupa menhir yakni berupa batu lempeng (pipih) dengan ketebalan batu sekitar $10 \mathrm{~cm}$, dengan panjang 120 $\mathrm{cm}$ dan lebar $28 \mathrm{~cm}$. Kondisi menhir sudah tidak berdiri lagi namun telah rubuh rapat dengan permukaan makam/gundukan tanah. Makam kuno tersebut berorientasi utara selatan, hal ini berarti menunjukkan adanya pengaruh Islam. Dapat diduga makam kuno ini memiliki assosiasi dengan batu meja di sebelah timurnya. Artinya, orang yang dimakamkan merupakan pendukung dar kebudayaan atau tradisi megalithik dengan menggunakan sarana batu meja sebagai media ritual. Meskipun melihat orientasi makam, menunjukkan bahwa orang yang dimakamkan tersebut sudah mendapat pengaruh Islam, namun tradisi ritual nenek moyang dengan media batu meja tetap dijalankan (Tim Penelitian, 2007 :14

Melihat temuan berbagai sesajen $\mathrm{d}$ sekeling betu meja serta adanya pecahan tempayan tanah liat, memunjukkan bahwa batu meja tersebut masih dimanfaatkan penduduk sampai sekarang sebagai sarana upacara ritual. Hubungannya dengan batu meja yang berassosiasi dengn makam kuno Islam, serta adanya konteks tradisi atau ritual yang berlanjut, bisa disimpulkan bahwa tradisi megalitihik masih berlangsung terus sejak masa awal pengaruh Islam hingga saa ini.

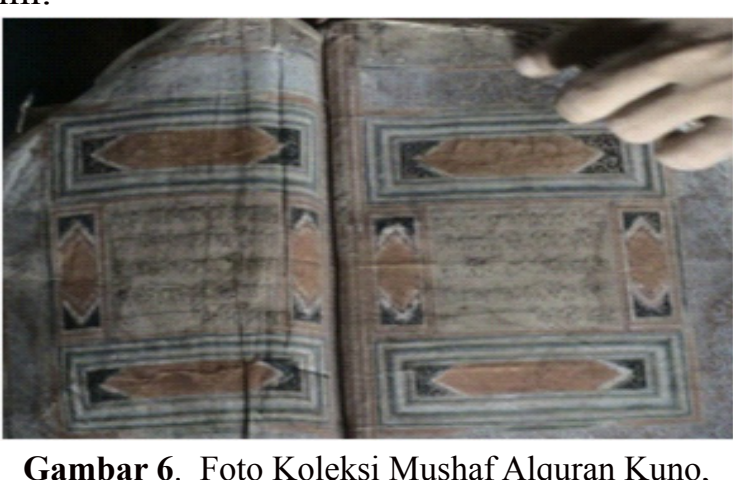

Gambar 6. Foto Koleksi Mushaf Alquran Kuno, Koleksi marga Husema

(Sumber: Dokumen Balai Arkeologi Ambon, 2009)

Ketiga, Situs Pulau Buano, temuan arkeologi Islam yang penting adalah alquran Kuno dan makam kuno. Alquran kuno dibawa oleh marga Husemahu, difungsikan pada hari ramadhan, dibawa ke masjid di simpan $d$ rumah adat Husemahu. Alquran ini terbuat dari sejenis kertas dengan tingkat kekerasan serat kertas yang tinggi. Di beberapa bagian kertas yang rusak, menunjukkan adanya serat kertas yang cukup kuat. Kemuingkinan kertas ini produk luar, hanya saja, tidak ada tandatanda logo tertentu yang tertera pada kertas ketika diterawang di sinar matahari secara langsung. Dari gaya tulisannya, tampak sekali alquran ini dhasilkan dari tulisan tangan. Adanya alqur an kuno bisa menjadi bukti bahwa pengaruh Islam sudah sangat kuat di daerah itu. Alquran kuno salah satu fungsinya kemungkinan sebagai medium untuk sosialisasi ajaran Islam di daerah itu, baik masa awal maupun masa perkembangan Islam di wilayah itu (Tim Penelitian, 2009: 10).

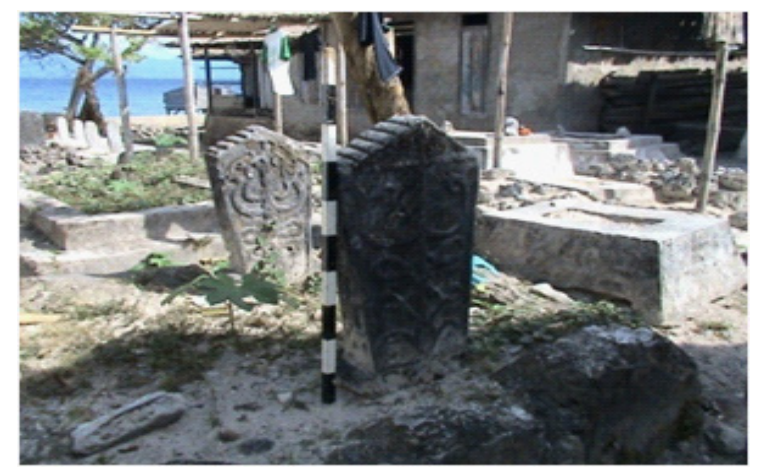

Gambar 7. Foto Salah satu bentuk makam kuno tipe Ternate, yang diduga sebagai makam penyebar Islam utusan Sultan Ternate

(Sumber: Dokumen Balai Arkeologi Ambon, 2009)

Selain Alquran Kuno, juga terdapat makam kuno. Situs makam kuno ini terdiri terdiri dari 6 (enam) buah makam kuno yang terletak ditengah-tengah atau diantara pemukiman penduduk.

Kompleks makam kuno ini terletak di bagian selatan masjid desa Buano Utara. Makam pada umumnya terdiri dari jirat yang dibuat dari susunan batu karang berwarna hitam. Sedangkan nisan menunjukkan teknologi yang lebih maju, yakni nsian terbuat dari batu karang berwarna hitan yang telah dipahat atau dihaluskan membentuk prisma, di bagian atasnya meruncing atau mebentuk segitiga sedangkan bagian badan dan pangkalnya membentuk persegi panjang. Ukuran tinggi nisan antara $50-70 \mathrm{~cm}$, lebar pangkal antara $20-30 \mathrm{~cm}$, lebar bagian atas 30-40 cm. Dengan demikian bentuk nisan menunjukkan semakin ke atas semakin melabar. Nisan pada umnya dieri motif hias sulur-sulur dan bentk motif hias trisula yang dibentuk dari motif sulur. Makam kuno pada umumnya menunjukkan makam dengan tipologi hiasan makam Tipe ternte sedangkan bentuknya lebih identik dengan makam tipe Demak (Tim Penelitian, 2009: 11-12)

Keempat, data arkeologi di Wilayah Pulau Manipa. Dalam tinjauan singkat di Pulau Manipa, tepatnya di desa Tumeluhu, terdapat masjid kuno yang kemungkinan di bangun pada awal abad ke $19 \mathrm{M}$.

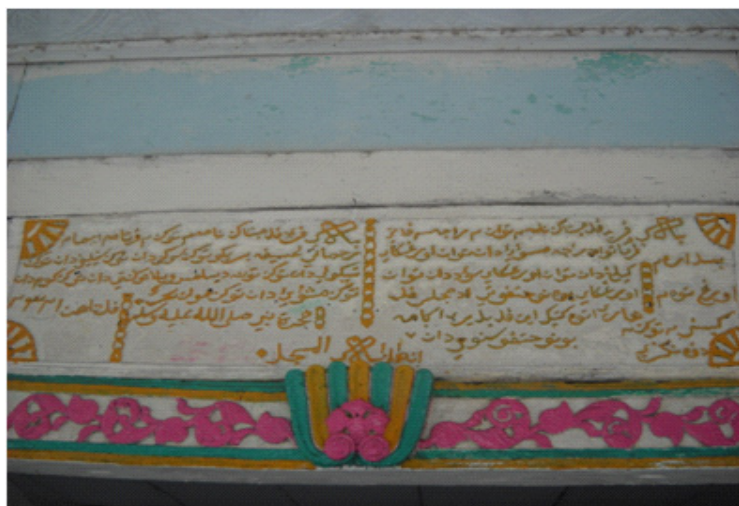

Gambar 8. Foto Prasasti yang tertera di atas pintu

masuk Masjid Ku

(Sumber: Dokumen Pribadi, 2012)

Dalam prasasti atau keterangan pembangunan masjid yang ditulis di atas pint masuk tertera angka 1232, sebagai angka tahun pendirian masjid. Namun angka itu tampaknya menunjukkan angka hijiriah. Jadi kemungkinan pembangunan masjid tahun $232 \mathrm{H}$, atau kira-kira sama dengan $1811 \mathrm{M}$

Di atas pintu masjid tertera, tulisan berhuruf Arab, Bahasa Melayu, sebaga berikut :

Pasal 1:

Bab peri pada menyatakan nama-nama tuanuan raja masowoi dan tuan raja pati

uang raja Masawoi dan Tuang Raja Kelang tuan orang kaya dan tuang orang Saude, dan pada hari itu pada berdiri agah, a buje has putih sanumi-sanumi dan babul masjid

Pasal 2

Bab peri pada menyatakan nama-nama ukang-tukang pertama:

. Rahmate lausepa. 2 Tukan Suku 3. Tukan Salisi 4. Tukan Tiakoly 5. Tukan Tuna, dilepas wabilatu ganti dengan Tukan kum dan Tukan Masawoi dan tukan Maulna Bahrun Mihrab, Nabi SAW dan bab pintu
masjid pada tahun $1232 \mathrm{H}$

Bab peri pada menyatakan

Nama-nama penghulu

Imam Suku dan Robo dan Modim Saman. Bab pada menyatakan nama-nama orans

2. Orang tua leka uku an orang tua salisi dan orang tua kasila ini haja babun 


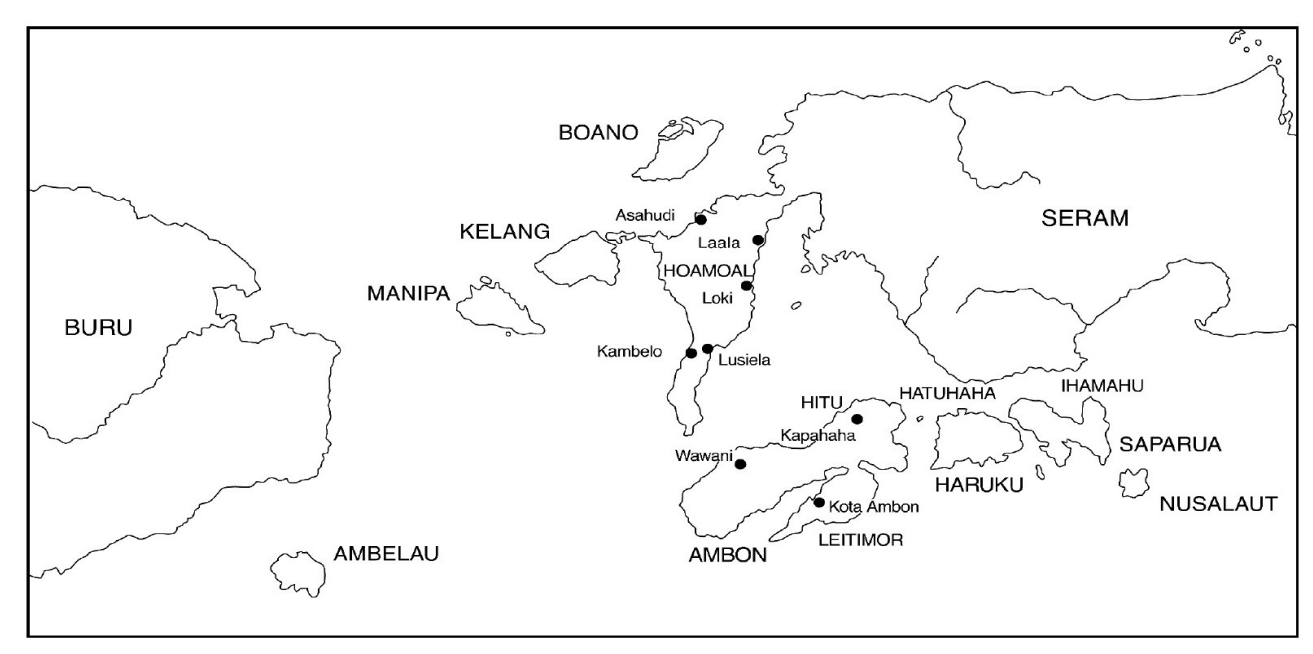

Gambar 9. Peta Hoamoal

(Sumber: Gerith Knaap, 2004:20)

Prasasti tulisan Arab berbahasa melayu yang tertera di atas pintu masjid, secara garis besar sesungguhnya menerangkan perihal proses pembangunan masjid dan kronologi pendirian masjid tua tersebut. Dalam proses pendirian masjid, diterangkan bahwa proses pendirian masjid dilakukan melalui proses musyawarah oleh para pemuka masyarakat. Penjelasan itu dapat diartikan bahwa pada masa masjid didirikan oleh para pemuka masyarakat, menandai bahwa Islam telah diterima secara resmi sebaga agama resmi pada tahun $1232 \mathrm{H}$. Selanjutnya prasasti itu juga menerangkan nama-nama marga yang bertugas sebagai imam, modin (muadzin, yang bertugas melafalkan azan) serta yang bertindak sebagai khutbah. Selain itu juga tercatat nama-nama marga yang terlibat sebagai tenaga pertukangan dalam membangun masjid.

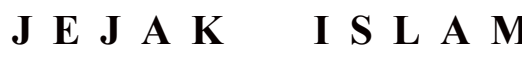

D A N

Data arkeologi yang ditemukan di wilayah Kerajaan Hoamoal, baik secara langsung maupun tidak langsung dapa memberi petunjuk tentang Islamisasi di wilayah ini. Jika dalam catatan sejarah bahwa Hoamoal merupakan bagian dari kekuasaan Ternate. Data arkeologi meskipun tidak dapa Ternate dan Hoamoal, namun menyangkut Islamisasi di wilayah ini dapat saling dikaitkan. Data arkeologi dapat memberikan gambaran tentang Islamisasi, sehingga memiliki pertautan atau dapat mengkonfirmasi data yang berasal dari Ternate.

Dalam tulisan Leirizza (1973) pengaruh Ternate di wilayah Luhu sudah tampak ketika wakil Ternate pada tahun 1605 yakni Gimelaha Besi Frangi ditempatkan di wilayah Hoamoal yakni sebuah tempat bernama Gamsugi, suatu tempat khusus yang didirikan di kota pelabuhan Luhu di pantai timur jazirah Hoamoal (Seram Barat) Gimelaha Bassi ini memerintah hingga tahun 1611 atau 1612 (Leirizza, 1973:86). Penjelasan selanjutnya adalah bahwa ciri penting dari daerah yang diperintah oleh Gimelaha adalah meluasnya agama Islam. Masjid-masjid dan surau-surau merupakan budaya yang terdapat di hampir setiap negeri, terutama negeri-negeri di pantai.

Penjelasan sejarah ini sesuai dengan data arkeologi yang ditemukan, baik data monumental. Survei arkeologi, menemukan bukti-bukti perkembangan kerajaan Islam Hoamoal, di antaranya di Negeri Luhu yang ditempati penduduk sekarang. Bukti-bukt adanya perkembangan Islam misalnya, adalah Masjid Jami Luhu, yang sudah banyak mengalami perubahan, kecuali di bagian tengah masjid, yang ditandai oleh sokoguru, berjumlah empat buah tiang. Selain itu terdapat beberapa makam keturunan raja, diantaranya yang masih mencirikan makam kuno dengan bentuk makam jirat terbuka dengan nisan menhir yakni makam keturunan Payapo salah satu marga Raja, yang terletak di depan masjid. Selain itu banyak benda-benda koleksi penduduk, berupa senjata-senjata tradisional, yang kemungkinan difungsikan pada masa perang Hoamoal abad ke $17 \mathrm{M}$, diantaranya, pedang, tombak dan sebagainya. Selain itu juga koleksi penduduk yang diduga sebagai alat-alat perlengkapan masjid kuno diantaranya lampu kuningan dan Alquran kuno jenis cetakan yang kemungkinan dicetak pada akhir abad ke $19 \mathrm{M}$.

Berdasarkan temuan arkeologi, sejarah tentang Islamisasi wilayah Hoamoa arkeologi berbentuk artefak maupun bangunan
Tentang aktifitas dagang, selain orangorang Cina tidak menutup kemungkinan adanya interaksi dengan Kerajaan Ternate yang memang dikenal telah lama memiliki kontak dengan Kepulauan Maluku bagian selatan. Di wilayah Buano sampai saat in terdapat marga yang secara turun temurun telah bermukim dan menjadi penduduk as Pulau Buano yang leluhurnya berasal dari Ternate yakni marga Nurlette. Persentuhan wilayah Buano dan Kelang dengan budaya Islam, selain berasal dari Ternate, tidak menutup kemungkinan baik langsung maupun tak langsung, juga pengaruh pedagang Persia dan Arab, juga pengaruh Islam dari Jawa. Sementara persentuhan dengan para pedagang China, pada abad $17 \mathrm{M}$ menunjukkan pad abad itu aktivitas perdagangan di wilayah tersebut berlangung pesat.

Survei arkeologi di daerah kekuasaan Kerajaan Hoamoal, yakni Pulau Manipa, Kelang dan Buano juga menemukan datadata pendukung tentang gerakan Islamisasi di wilayah kerajaan ini, di Pulau Manipa dterdapa masjid kuno yang di bangun sekitar abad 18 $\mathrm{M}$, meskipun dalam kepercayaan penduduk, masjid di bangun abad ke $12 \mathrm{M}$. Angka tahun Islam di atas pintu masjid, menunjukkan tahun $1231 \mathrm{H}$, yang menunjukkan abad $18 \mathrm{M}$. Data arkeologi yang lebih tua, kemungkinan terdapat di Pulau Buano, selain Alquran kuno yang kemungkinan ditulis abad ke 16-17 M, juga terdapat kompleks makam kuno, yang kemungkinan makam para penyiar Islam. Tipologi makam menunjukkan tipologi makam Ternate (Tim Penelitian, 2009:12).

Di wilayah daratan Hoamoal ditemukan situs yang kemungkinan dimanfaatkan sebaga benteng pertahanan tradisional, yakni Situs Batu Kapal. Situs batu kapal ditandai oleh temuan struktur atau susunan batu keliling, yang menandai sebagai situs pertahanan sekaligus sebagai hunian. Areal rata, dengan lanskap perbukitan landai dekat daerah pantai serta sumber air yang cukup, sanga startegis sebagai lokasi pertahanan sekaligus hunian. Bukti-bukti hunian ditemukan adanya sebaran gerabah dan keramik dari periode 
Ming (abad 14-16 M) dan Qing (17-19 M). Temuan keramik asing di dominasi oleh keramik Qing, yang menandakan bahwa situs tersebut intensif digunakan pada abad $17 \mathrm{M}$ yang jika dikonfirmasi dengan data sejarah, menunjukkan periodesasi akhir pemerintahan Islam Kerajaan Hoamoal, karena pada periode tersebut, hegemoni VOC telah menguasai Kerajaan Hoamoal.

Pada masa puncak kejayaannya, Kerajaan Hoamoal tercatat dalam berbaga sumber lisan, mengembangkan wilayah kekuasaannya di wilayah pulau-pulau keci di sekitar pesisir selatan Pulau Seram Bagian Barat. Dalam sumber tutur disebutkan Pula Kelang, Buano dan Manipa merupakan wilayah kekuasaan Hoamoal sekaligus basi pertahanan terluar dari Kerajaan Hoamoal. Temuan arkeologi, berupa peninggalan peninggalan Islam di wilayah tersebu mengindikasikan mendapat pengaruh Islam, baik secara langsung dari wilayah Kesultanan Ternate maupun dari Kerajaan Hoamoal.

Dalam catatan sejarah, Luhu dalah kota pelabuhan dari Kerajaan Hoamoal. Kejayan Kerajaan Luhu (Hoamual) mengalami keruntuhan akibat kekerasan Bangsa Belanda yang ingin monopoli hasil cengkeh di Kerajaan (Hoamual) selama kurang lebih 31 Tahun, disertai dengan penebangan cengkeh (Ekstirpasi) oleh pasukan Hongitochtennya. Perang yang berlangsung dari tahun 1625-1656 itu dikena dengan nama perang Hoamual. Perang tersebut berhasil meluluh lantakan sendisendi kehidupan Kerajaan Hoamual. Paska perang Hoamual tepatnya mulai tanggal 6 Maret 1656 Belanda melakukan deportasi (pemindahan penduduk secara paksa) yang adalah merupakan sebagian dari politik pecah belah (Devide et Impera). Akhirnya, kekuasaan Kerajaan Hoamual yang dulu meliputi 99 desa / dusun, kini hanya tingga sebuah desa yaitu Desa Luhu dengan 16 dusun bawahannya.

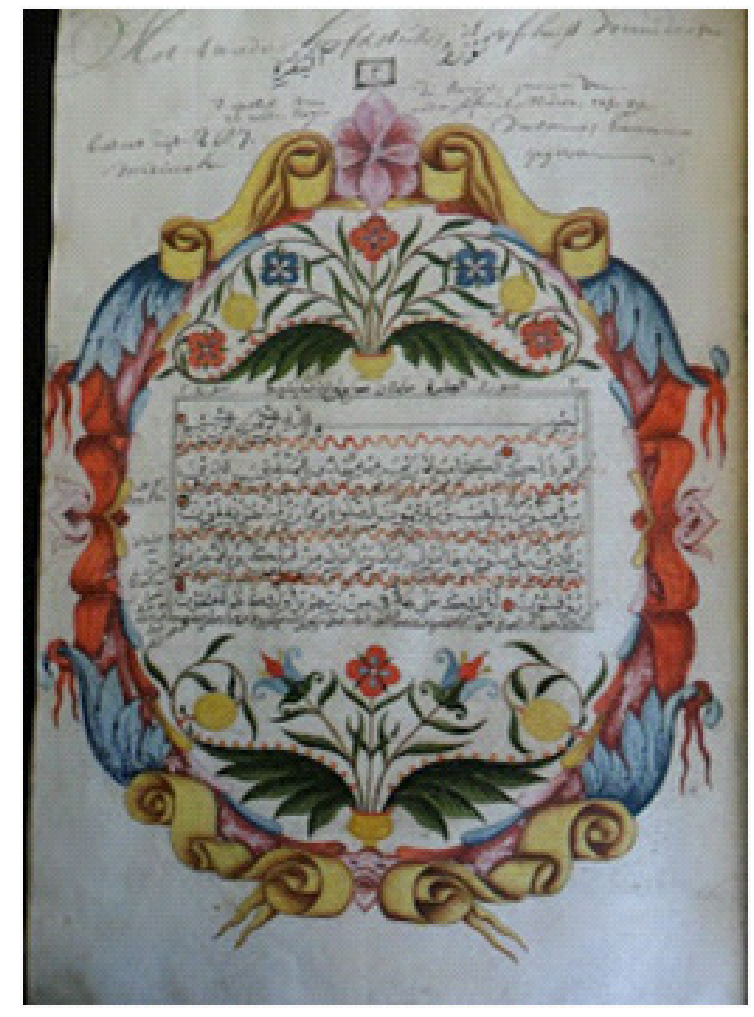

Gambar 10. Foto. Mushaf Alquran dari Pul
Manipa, Koleksi Universitas Leiden.

(Sumber: Litbang Kementerian Agama, 2012

Dalam sejarah disebutkan bahwa setelah dikuasai atau ditaklukkan, VOC, banyak masyarakat Kerajaan Hoamoal meninggalkan negeri dan mencari pemukiman baru. Berdasarkan tradisi tutur masyarakat di Pulau Buano dan Manipa, masyarakat dari Hoamoal sebagian diantaranya mendirikan pemukiman baru ke Pulau Buc Manipa. Di Pulau Manipa dukungan data Mushaf Alquran Kuno koleksi Perpustakaan Universitas Leiden memperkuat penjelasan tentang puncak perkembangan Islam pada abad 17 M. Mushaf Alquran kuno tersebut bertarikh $1694 \mathrm{M}$ ditulis di Pulau Manipa oleh Batu Langkai, imam Tomilehu (Akbar, 2012 15 ). Meskipun pada masa itu pengaruh Eropa juga sangat kuat, namun tradisi Islam melalui penulisan mushaf Alquran menunjukkan bahwa perkembangan syiar Islam justru meningkat.

\section{PENUTUP}

Berdasarkan hasil penelitian baik berupa data arkeologi maupun pelacakan atas sumber-sumber literatur, maka Kerajaan Hoamoal tak dapat disangsikan lagi merupakan sebuah wilayah kerajaan yang mendapat pengaruh dari wilayah pusat kekusaaan Islam Ternate di Maluku Utara. Meskipun secara lokalitas, terdapat sanggahan atas kekuasaan Ternate di Hoamoal, namun bukti-bukti cukup menerangkan bahwa Hoamoal bagian dari ekspansi kekuasaan Ternate sebagaimana banyak diuraikan dalam catatan sejarah lokal.

Bukti-bukti arkeologi maupun sejarah memberikan penekanan pada bukti kekuasaan Ternate atas Hoamoal. Berdirinya Masjid Jami Luhu menadai berdirinya sebuah kerajaan yang dapat dihubungkan dengan adanya pemerintahan pertama oleh utussan Ternate yang bergelar Gimelaha. Selain itu berbagai artefak di permukaan tanah dalam bentuk pecahan maupun artefak yang masih utuh koleksi penduduk seperti keramik asing membuktikan bahwa perkembangan aktifitas perdagangan semakin intensif setelah terbentuknya pemerintahan di Kerajaan Hoamoal. Data sejarah yang menyebutkan bahwa pemerintahan Islam Hoamoal berlangsung sejak awal abad ke $17 \mathrm{M}$ berkesesuaian dengan data artefaktual keramik asing yang juga menunjukkan kronologi mulai abad ke $17 \mathrm{M}$ dan selanjutnya berkembang hingga abad 18-19 ketika perdagangan bangsa Eropa semakin intensif. Hal ini mendukung penjelasan sejarah bahwa Islamisasi di wilayah Hoamoal mendapat pengaruh dari Ternate dan puncak Islamisasi berlangsung sejak awal abad $17 \mathrm{M}$ ketika utusan ternate memerintah di wilayah itu, dan berlangsur-angsur surut ketika hegemoni Kolonial melalui VOC menguasai wilayah serta menguasai monopoli perdagangan cengkeh yang menimbulkan perpecahan dan pada akhirnya Hoamoal dapat dihancurkan sampai kemudian pemerintahan Islam berakhir.

\section{DAFTAR PUSTAKA}

Akbar, Ali., 2012. Khasanah Mushaf Alqura Kuno Maluku. Pameran dalam Rangka Penyelenggaraan Musabaqah Tilawatil Quran (MTQ) Nasional XXIV Maluku. Latjnah Penthasihan Mushaf Alquran Badan Litbang dan Diklat Kementerian Agama RI

Leirissa R.Z., 1973. Kebijaksanaan VOC untuk mendapatkan Moniopoli Perdagangan Cengkeh di Maluku Tengah antara Tahu 1615 dan 1652, dalam Bunga Rampai Sejarah Maluku (1), Lembaga Penelitia Daerah Maluku, Jakarta.

Leirissa, R.Z., 2001. Jalur Sutera: Integrasi LautDarat dan Ternate sebagai Bandar di Jalur Sutera. Dalam M.J. Abdulrahman, et.al. Ternate: Bandar Jalur Sutera, LinTas (Lembaga Informasi dan Transformasi Sosial). Ternate

Patikayhatu, dkk., 2009. Sejarah Negeri dan Desa di Kota Ambon. Ambon: Dinas Pariwisata Kebudayaan, Pemuda dan Olahraga.

Mahmud, Irfan., 2001. Determinasi Budaya Islami di Wilayah Pinggiran Kekuasaan Bugis. WalannaE. Jurnal Arkeologi Sulawesi Selatan dan Tenggara. Vol IV No 6 Juni. Balai Arkeologi Makassar.

Putuhena, Shaleh 2001 Proses Perluasan Agama Islam di Maluku Utara. Dalam M.J. Abdulrahman, et.al. Ternate: Bandar Informasi dan Transformasi Sosial).

Ricklefs, M.C 2008 Sejarah Indonesia Modern 1200-2004. Jakarta. PT Serambi Ilmu Semesta.

Tjandrasasmitha, Uka 2009 Arkeologi Islam Nusantara. Jakarta. Kepustakaan Popule Gramedia (KPG).

Tim Penelitian, 2007 Survei Arkeologi di Kawasan Air Papaya dan Wayasel, Kecamatan Hoamoal Belakang. Lapora Penelitian. Balai Arkeologi Ambon. Tidak terbit

Tim Penelitian, 2009 Survei Arkeologi di Wilayah Pulau Kelang dan Buano. Lapora 
Penelitian. Ambon. Balai Arkeologi Ambon. Tidak terbit

Tim Penelitian, 2012 Penelitian Arkeologi Islamisasi di Wilayah Kerajaan Hoamoal. Lapoaran Penelitian. Ambon. Balai Arkeologi Ambon. Tidak terbit 